\title{
Effect of phosphorus in commercial fertilizers on phytoavailability cadmium and zinc uptake by sugarcane
}

\author{
P. Sampanpanish ${ }^{1,2}$, S. Ruangkhum ${ }^{1} \&$ C. Tongcumpou ${ }^{1,2}$ \\ ${ }^{I}$ National Center of Excellence for Environmental and Hazardous Waste \\ Management, Chulalongkorn University, Thailand \\ ${ }^{2}$ Environmental Research Institute, Chulalongkorn University, Thailand
}

\begin{abstract}
The effects of phosphorus in commercial fertilizers on concentrations of total cadmium $(\mathrm{Cd})$ and zinc $(\mathrm{Zn})$, plant-available $\mathrm{Cd}$ and $\mathrm{Zn}$ and sugarcane uptake of $\mathrm{Cd}$ and $\mathrm{Zn}$ were studied. A single rate $(312.5 \mathrm{~kg} / \mathrm{ha})$ of $16-16-8$ NPK fertilizer was applied on three levels $(0-3,3-20$ and $>20 \mathrm{mg})$ of $\mathrm{Cd}$ contaminated sugarcane cultivated field in Mae Sot district, Tak province. In order to investigate the effects of different rates of fertilizer application, 16-16-8 NPK fertilizer at the rate of $312.5,625$ and $1,250 \mathrm{~kg}$ fertilizer/ ha was applied to soils in a pot experiment and planted with a piece of mature cane stem. The pot experiment was conducted in a randomized block design with three replications. Repeat applications of fertilizer were made at the same rate in the fifth month of the cultivation for both field and pot experiments. Soil and sugarcane samples were collected at the end of the second and the sixth month respectively. After harvesting, sugarcanes were divided into five components: underground stems, roots, bagasses, juice and leaves. Chemical analysis of the field experiments showed that total $\mathrm{Cd}$ and $\mathrm{Zn}$ in sugarcane increased with $\mathrm{Cd}$ concentration in cultivated field and found that $\mathrm{Cd}$ and $\mathrm{Zn}$ mostly accumulated in roots. Longterm effects of fertilizer application was expected to be a concern although there was no higher $\mathrm{Cd}$ and $\mathrm{Zn}$ concentrations in soil after repeat fertilization in the fifth month of the cultivation. For the pot experiment, the results showed that higher $\mathrm{P}$ can make more $\mathrm{Cd}$ available and ease take up and accumulation in different parts of the sugarcane. Moderate $\mathrm{P}$ application rate reduced phytoavailability of $\mathrm{Zn}$ at the end of the second month because of the P-Zn mineral precipitation. However, the ability of sugarcane to uptake $\mathrm{Zn}$ increased again at the end of the sixth month of the cultivation at which time total $\mathrm{P}$ in the soil decreased. Total $\mathrm{Cd}$ and $\mathrm{Zn}$ in sugarcane were significantly increased with increasing 16-16-8 NPK fertilizer application rates and we found that $\mathrm{Cd}$ and $\mathrm{Zn}$ accumulated in sugarcane according to the following sequence: roots $>$ underground stems (setts) $>$ bagasses $>$ leaves $>$ juice.
\end{abstract}

Keywords: phosphorus, fertilizers, cadmium, zinc, phytoavailability, sugarcane. 


\section{Introduction}

Natural geochemical processes and anthropogenic activities are two major means of releasing hazardous substances, such as heavy metals, into the environment. Among the various metals, cadmium $(\mathrm{Cd})$ and zinc $(\mathrm{Zn})$ are two widespread harmful heavy metals. $\mathrm{Cd}$ is closely related to $\mathrm{Zn}$ and will be found wherever $\mathrm{Zn}$ exists in nature. Department of Primary Industries and Mines [1] reported elevated levels of $\mathrm{Cd}$ in paddy soils and rice grain downstream of a $\mathrm{Zn}$ mining area in Pra Tad Padang, Mae Ku and Mae Tao sub-district, Tak province. Over $90 \%$ of rice grain samples collected contained $\mathrm{Cd}$ at concentrations exceeding the Codex Committee on Food Additive and Contaminants (CCFAC) draft Maximum Permissible Level for rice grain of $0.2 \mathrm{mg} / \mathrm{kg}$. This level may cause health problems along the food chain. For this reason, it has become necessary to look economically efficient non-food crops to cultivate in $\mathrm{Cd}$ contaminated areas. Owing to the energy crisis in Thailand, sugarcane has been studied for use as a raw material for ethanol production. This led to the idea of sugarcane cultivation instead of rice farming in the affected areas. Meantime, the application of fertilizers has expanded rapidly in sugarcane cultivated fields in Tak province to promote sugarcane growth and improve the quality and quantity of sugarcane production.

Phosphorus (P) is one of the essential nutrients for plant growth. Plants need $\mathrm{P}$ for utilization of sugar and starch, photosynthesis, nucleus formation and cell division. However, a possible negative effect of $\mathrm{P}$ fertilizers is the contamination of cultivated lands by trace metals naturally present in the $\mathrm{P}$ rocks used to manufacture the fertilizers. Cd contaminate in phosphorus fertilizers is considered as one of the major sources of metal addition in agricultural soils. Moreover, contaminates could be taken up by plants and might accumulate in food chains. Many works have been done on the interaction between fertilizer application and the accumulation of $\mathrm{Cd}$ concentrations in soils and plants [2] and [3]. Tu et al. [4] examined the influence of nitrogen $(\mathrm{N}), \mathrm{P}$ and potassium $(\mathrm{K})$ fertilizers on the speciation distribution of lead $(\mathrm{Pb})$ and $\mathrm{Cd}$ in red soil in China. Their findings suggest that applying chemical fertilizers may change the speciation and thus phytoavailability of heavy metals. However, there is still little information on the transport and accumulation of heavy metals in plants as related to the nutritional levels in the soil environment. Therefore, the phytoavailability of $\mathrm{Cd}$ and $\mathrm{Zn}$ after applying different levels of fertilizer was examined in this study.

The objectives of this study were to (i) determine the effect of $\mathrm{P}$ in fertilizers on total cadmium (TCd) and total zinc (TZn) in soil at different application rates and (ii) determine the association between the concentration of $\mathrm{Cd}$ and $\mathrm{Zn}$ in sugarcane( $\mathrm{TCd}, \mathrm{TZn}$ ) and the available $\mathrm{Cd}$ and $\mathrm{Zn}$ in soils. 


\section{Methodology}

\subsection{Field experiment}

The field experiment was conducted in three sugarcane cultivation plots, located in Mae $\mathrm{Ku}$ and Mae Tao sub-district, Mae Sot, Tak province, which contained different levels of cadmium concentrations. The three locations include $\mathrm{Mae} \mathrm{Ku}$ (0-3 mg Cd/kg dry soil), Mae Tao 1 (3-20 mg Cd/kg dry soil), and Mae Tao 2 (>20 mg Cd/kg dry soil). Soils were collected to determine basic physical and chemical properties. Background $\mathrm{Cd}$ and $\mathrm{Zn}$ in soil were determined by USEPA method 3052 and found to contain $2.58,36.66,174.51$ and $2.35 \mathrm{mg} \mathrm{Cd} / \mathrm{kg}$ dry soil and 35.12, 74.86, 2,098.67 and $28.00 \mathrm{mg} \mathrm{Zn/kg} \mathrm{dry} \mathrm{soil} \mathrm{for} \mathrm{Mae} \mathrm{Ku,} \mathrm{Mae}$ Tao 1, Mae Tao 2 and soil used in pot experiment, respectively.

All of these areas received an initial application of granular commercial NPK fertilizer (16-16-8) at the rate of $312.5 \mathrm{~kg} / \mathrm{ha}$ and a repeat application after five months. The fertilizer was analysed for heavy metal content and found to contain $0.39 \mathrm{mgCd} / \mathrm{kg}$ fertilizer and $26.82 \mathrm{mgZn} / \mathrm{kg}$ fertilizer. Three replicates of soil and sugarcane samples were collected at the end of the second and sixth month of the cultivation. Sugarcane samples were taken from the same area used in soil sample collection.

\subsection{Pot experiment}

\subsubsection{Soil preparation}

Soils collected from Mae Ku district, Mae Sot, Tak province were used in the pot experiment. The Soil was collected from $0-30 \mathrm{~cm}$ below surface horizon and allowed to air dry before being crushed to pass through a 2-mm sieve.

\subsubsection{Plant preparation}

Cut pieces of mature sugarcane stems (setts), LK 92-11 ecotype, were obtained from Kampangpetch province. The USEPA method 3052 was used for the analysis of background $\mathrm{Cd}$ and $\mathrm{Zn}$ in plant (setts) samples. Levels were nondetectable.

\subsubsection{Experimental design and procedure}

The experiment was conducted in a randomized block design with three replications with $20 \mathrm{~kg}$ of soil per pot. Each pot was planted with a sett. A month later, the first application of fertilizer was conducted. A granular commercial NPK fertilizer formulation (16-16-8) was applied to each pot at the rate of 0 (control group), 312.5, 625 and 1,250 kg fertilizer/ha. The control group did not receive any fertilizer addition, but was subjected to all other manipulation steps. Repeat applications of fertilizer were conducted at the same rate after four months (the fifth month of cultivation). Soil and sugarcane samples were collected at the end of the second and sixth month of the cultivation. 


\subsection{Sample preparation}

Soils were dried at $105^{\circ} \mathrm{C}$ for $24 \mathrm{hr}$ to constant weight and then they were crushed to pass through a $2-\mathrm{mm}$ sieve and thoroughly mixed to homogenize. For the analysis of available $\mathrm{Cd}$ and $\mathrm{Zn}$ in soil, soil samples were air-dried for $72 \mathrm{hr}$ and then crushed to pass through a 2-mm sieve and mixed to homogenize before analysis. Sugarcane samples were cleaned and washed with tap water twice and rinsed with deionized water and then they were divided into five parts: underground stems (setts), roots, bagasses, sugarcane juice and leaves. Samples were dried at $105^{\circ} \mathrm{C}$ for $24 \mathrm{hr}$ to constant weight and dry matter yields were determined. After that, they were ground with electric mill and thoroughly mixed to homogenize.

\subsection{Sample analysis}

TCd and TZn in soil and sugarcane (underground stems, roots, bagasses and leaves) were determined by the USEPA method 3052 [5]. Sugarcane juice was analyzed by digestion in a mixture of 10: $1: 4(\mathrm{v} / \mathrm{v} / \mathrm{v})$ of $\mathrm{HNO}_{3}(14 \mathrm{M}), \mathrm{H}_{2} \mathrm{SO}_{4}$ $(36.8 \mathrm{M})$ and $\mathrm{HClO}_{4}(15.3 \mathrm{M})$ [6]. The digested solution was analyzed by graphite furnace atomic absorption spectroscopy. Total $\mathrm{P}$ in soil was determined by vanadomolybdate method [7]. Available $\mathrm{Cd}$ and $\mathrm{Zn}$ in soil were estimated by DTPA extraction method $\left(0.005 \mathrm{M}\right.$ DTPA+ $\left.0.01 \mathrm{M} \mathrm{CaCl}_{2}\right)[8]$.

\section{Results and discussions}

\subsection{Concentration of phosphorus in soils}

Under the field conditions, total $\mathrm{P}$ in the three locations with different $\mathrm{Cd}$ contaminated levels were examined. Concentration of total $\mathrm{P}$ in Mae $\mathrm{Ku}$ area $(<$ $3 \mathrm{mg} \mathrm{Cd} / \mathrm{kg}$ ) is lower at the end of the sixth month when compared to the second month even though a repeat application of fertilizer was conducted. For Mae Tao $1(3-20 \mathrm{mg} \mathrm{Cd} / \mathrm{kg})$ and Mae Tao $2(>20 \mathrm{mg} \mathrm{Cd} / \mathrm{kg})$, total P in soils at the end of the sixth month of the cultivation increased and was higher than in the second month. Total $\mathrm{P}$ in 625 and $1,250 \mathrm{~kg}$ fertilizers/ha treatment increased at the end of the sixth month by an average of $13.57 \%$ and $31.71 \%$, respectively.

For the pot experiment, at the end of the second month of the cultivation, total $\mathrm{P}$ in all treatments of fertilized soil increased with increasing fertilizer application rates and total $\mathrm{P}$ in $1,250 \mathrm{~kg}$ fertilizers/ha treatment was increased by an average of $9.4 \%$ above the control group ( $0 \mathrm{~kg}$ fertilizer/ ha). Concentration of total $\mathrm{P}$ in all treatments in the sixth month also gradually increased with fertilizer application rates. However, they were lower when compared to the second month's group even though a repeat application of fertilizer was conducted. This may be due to increased crop uptake of $\mathrm{P}$ during the peak rate of sugarcane growth. This result indicated that further additions of fertilizer are often required in order to maintain high crop yields. McLaughlin and Singh [9] mentioned that one of the reasons that $\mathrm{P}$ must be repeatedly applied to soils is to overcome the slow $\mathrm{P}$ fixation reactions. 


\subsection{TCd and TZn in soil}

As figure 1 shows, $\mathrm{Cd}$ concentration in the soil from the three areas with $\mathrm{Cd}$ contamination of $0-3,3-20$ and $>20 \mathrm{mg} \mathrm{Cd} / \mathrm{kg}$ were $2.34,34.03$ and 172.77 $\mathrm{mgCd} / \mathrm{kg}$ respectively and $\mathrm{Zn}$ concentrations were $33.44,71.48$ and 2,091.54 $\mathrm{mgZn} / \mathrm{kg}$ respectively, at the end of the second month. $\mathrm{Cd}$ and $\mathrm{Zn}$ concentration in field experiment soil decreased about $25 \%$ and $30 \%$, respectively at the end of the sixth month. The results indicated no effect from $312.5 \mathrm{~kg} / \mathrm{ha}$ NPK fertilizer application and repeat application which may be due to a low concentration of $\mathrm{Cd}$ and $\mathrm{Zn}$ in the fertilizer.
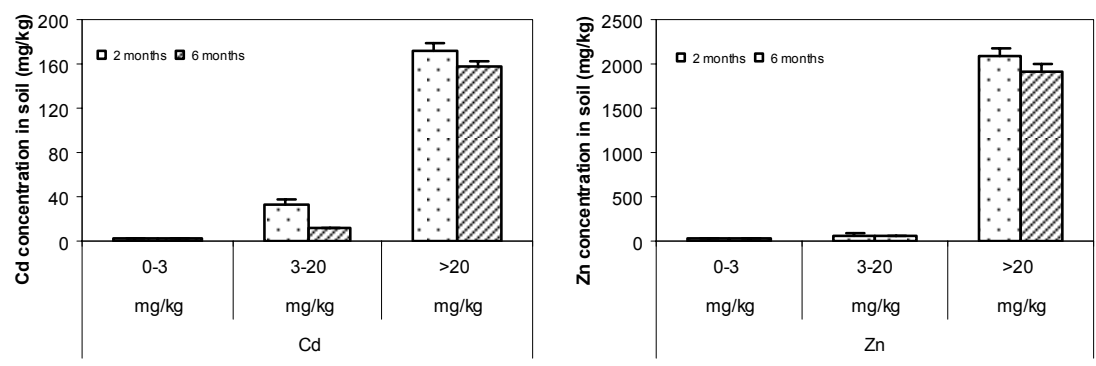

Figure 1: Effect of different fertilizer application rates on TCd and TZn in field experiment soil.

The results showed in the pot experiment that the concentrations of TCd in soil were gradually lowered in all three levels of fertilized soil at the end of the second and sixth months of the cultivation (table 1). The results tend to suggest that fertilization is not increasing levels of total $\mathrm{Cd}$ in soils, but may instead to be decreasing $\mathrm{Cd}$ concentrations because of effect of $\mathrm{P}$ addition in increasing ability of $\mathrm{Cd}$ to taken up by plant tissues. The reduction of $\mathrm{Cd}$ adsorption in the presence of phosphate in soils was reported by Krishnamurti et al. [10]. Because of the presence of $\mathrm{Zn}$ as an impurity in the fertilizer used in this study, the results do not show any clear relationship between TZn accumulated in soils and the 1616-8 NPK fertilizer application rate in either the end of the second or sixth

Table 1: $\quad$ Effect of different fertilizer application rates on TCd and TZn in pot experiment soil.

\begin{tabular}{|l|c|c|c|c|}
\hline \multirow{2}{*}{$\begin{array}{l}\text { Fertilizer application } \\
\text { rates (kg/ha) }\end{array}$} & \multicolumn{2}{|c|}{ Total Cd (mg/pot) } & \multicolumn{2}{c|}{ Total Zn (mg/pot) } \\
\cline { 2 - 5 } & 2 months & 6 months & 2 months & 6 months \\
\hline 0 (control group) & $47.132 \pm 1.509^{a}$ & $46.991 \pm 1.611$ & $559.710 \pm 32.007$ & $558.772 \pm 33.007$ \\
\hline 312.5 & $47.134 \pm 1.111$ & $47.002 \pm 2.018$ & $559.676 \pm 24.004$ & $558.652 \pm 41.004$ \\
\hline 625 & $47.061 \pm 2.027$ & $46.972 \pm 1.115$ & $559.650 \pm 22.009$ & $558.726 \pm 50.009$ \\
\hline 1,250 & $47.011 \pm 1.614$ & $46.963 \pm 1.215$ & $559.728 \pm 41.018$ & $558.934 \pm 20.018$ \\
\hline
\end{tabular}

${ }^{a}$ Mean \pm Standard deviation. 
month as presented in table 1. Concentrations of TZn in soil were lower in the 312.5 and $625 \mathrm{~kg}$ fertilizer/ha as compared to the non-fertilized soil $(0 \mathrm{~kg}$ fertilizer/ha). However, total $\mathrm{Zn}$ accumulated in soil at 1,250 kg fertilizer/ha treatment was higher than in non-fertilized soil. This could result from the application of fertilizer containing $\mathrm{Zn}$ in amounts exceeding crop uptake which will inevitably result in an accumulation of $\mathrm{Zn}$ in soil. In addition, a higher soil $\mathrm{Zn}$ can then enhance more $\mathrm{Cd}$ desorption, and hence, increase $\mathrm{Cd}$ concentration in the soil solution which might then increase $\mathrm{Cd}$ phytoavailability [11]. Thus, this may affect lower of $\mathrm{Cd}$ concentration in soil in the $1,250 \mathrm{~kg}$ fertilizer/ha treatment.

\subsection{Available Cd and $\mathrm{Zn}$}

Under the field conditions, an increase of available $\mathrm{Cd}$ and $\mathrm{Zn}$ in field experiment soils was proportional to the level of $\mathrm{Cd}$ contaminate in the sugarcane cultivated areas. Available $\mathrm{Cd}$ and $\mathrm{Zn}$ increased in the sixth month of the cultivation (table 2). This can be a result of high $\mathrm{Cd}$ contaminate in sugarcane cultivated areas and not an effect of the phosphorus nutrient contained in the fertilizer.

Table 2: $\quad$ Available $\mathrm{Cd}$ and $\mathrm{Zn}$ in different levels of $\mathrm{Cd}$ contaminated areas.

\begin{tabular}{|l|c|c|c|c|}
\hline \multirow{2}{*}{ Location } & \multicolumn{2}{|c|}{ Available Cd (mg/kg) } & \multicolumn{2}{c|}{ Available Zn (mg/kg) } \\
\cline { 2 - 5 } & 2 months & 6 months & 2 months & 6 months \\
\hline Mae Ku & $0.055 \pm 0.017^{a}$ & $0.247 \pm 0.012$ & $1.079 \pm 0.010$ & $1.991 \pm 0.012$ \\
\hline Mae Tao 1 & $0.189 \pm 0.004$ & $0.327 \pm 0.006$ & $3.258 \pm 0.004$ & $4.489 \pm 0.004$ \\
\hline Mae Tao 2 & $18.521 \pm 0.015$ & $30.457 \pm 0.007$ & $154.774 \pm 0.009$ & $216.563 \pm 0.016$ \\
\hline
\end{tabular}

${ }^{a}$ Mean \pm Standard deviation.

For the pot experiment, the results showed that an increasing of the 16-16-8 NPK fertilizer application rates also increased availability of $\mathrm{Cd}$ at the end of the second and sixth months of the cultivation (figure 2). Higher P contained in the fertilizer would be likely to enhance the $\mathrm{Cd}$ uptake by the plant or phytoavailability of $\mathrm{Cd}$ in soil. Phytoavailability of $\mathrm{Zn}$, at the end of the second month, was lower in all rates of fertilized soil as compared to non-fertilized soil ( $0 \mathrm{~kg}$ fertilizer/ha). The decrease in $\mathrm{Zn}$ with fertilizer addition strongly suggests enhanced $\mathrm{Zn}$ adsorption on the surface due to $\mathrm{P}$ inputs or $\mathrm{P}-\mathrm{Zn}$ mineral precipitation. Mench et al. [12], McGowen et al. [13] and Cotter-Howells and Caporn [14] proposed precipitation of $\mathrm{P}-\mathrm{Zn}$ minerals as the mechanism reducing solution concentrations of $\mathrm{Zn}$ in soils. This is consistent with Choudhary et al. [15] and Grant and Bailey [16], they reported that $\mathrm{Zn}$ in soils would occupy most of the newly-formed adsorption sites created by the $\mathrm{P}$ addition; or consume phosphate for precipitation and would allow available $\mathrm{Cd}$ to increase with the fertilizer applications. However, the lower solution $\mathrm{Zn}$ (available $\mathrm{Zn}$ ) with the fertilizer addition does not show any clear relationships between $\mathrm{Zn}$ in soil extracts and fertilizer addition, especially when one considers that a fair amount 
of $\mathrm{Zn}$ was added as a contaminant in the fertilizer [17]. At the end of the sixth month, $\mathrm{P}$ in soil in all treatments appears to be lower than in the second month because of using $\mathrm{P}$ in plant growth. Thus, the $\mathrm{P}-\mathrm{Zn}$ mineral precipitation is decreased and it can induce higher phytoavailability of $\mathrm{Zn}$.
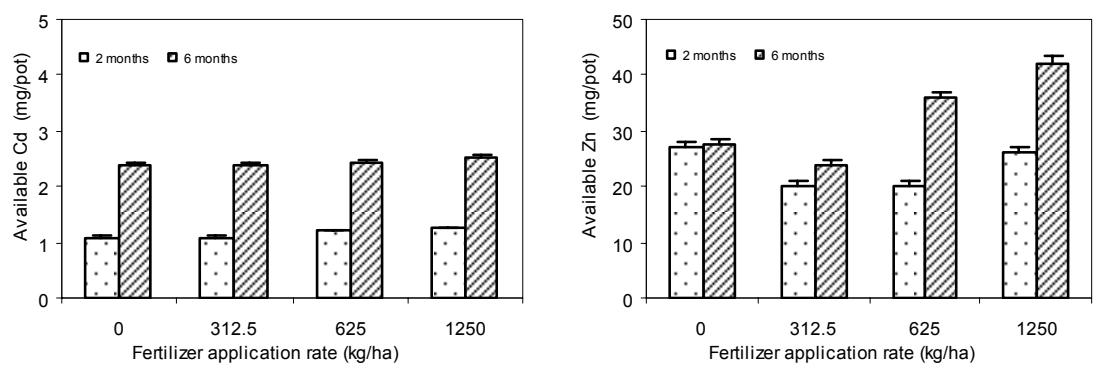

Figure 2: $\quad$ Effect of different fertilizer application rates on available $\mathrm{Cd}$ and $\mathrm{Zn}$ in pot experiment.

\subsection{TCd and TZn accumulation in sugarcane}

$\mathrm{Cd}$ and $\mathrm{Zn}$ taken up in sugarcane also increased with the proportion present in sugarcane cultivated areas. The decreases of $\mathrm{Cd}$ and $\mathrm{Zn}$ accumulation in sugarcane at the end of the sixth month are the result of increasing sugarcane growth and dry matter yield (figure 3 ). The accumulation of $\mathrm{Cd}$ and $\mathrm{Zn}$ in different parts of the sugarcane had the following sequence: roots $>$ underground stems (setts) $>$ bagasses $>$ leaves $>$ juice (figure 4 ).
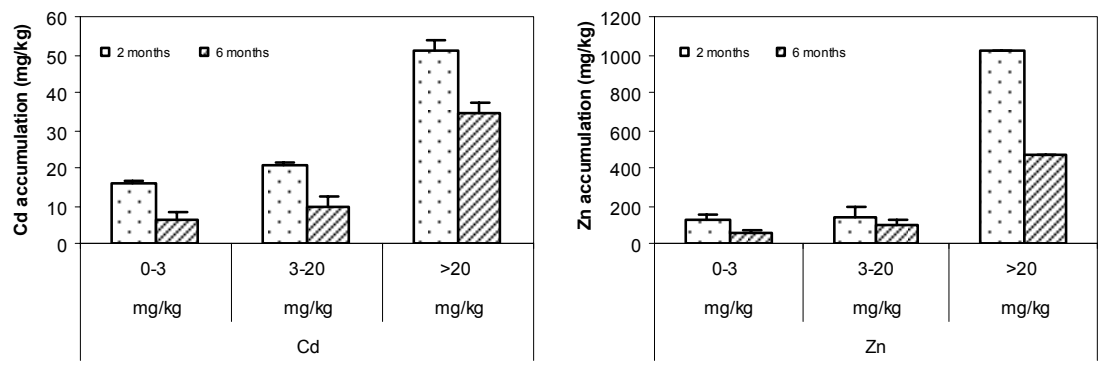

Figure 3: $\quad \mathrm{Cd}$ and $\mathrm{Zn}$ accumulated in field experiment sugarcane.

In the pot experiment, the results illustrated in figure 5 shows that the concentration of TCd in sugarcane was gradually promoted with increasing of 16-16-8 NPK fertilizer application rates and found that $\mathrm{Cd}$ and $\mathrm{Zn}$ are mostly accumulated in the $1,250 \mathrm{~kg}$ fertilizers/ha treatment. Cd accumulation in sugarcane at the end of the second and sixth months of the cultivation were 161.91 and $288.30 \mu \mathrm{g} \mathrm{Cd} /$ plant, respectively and $\mathrm{Zn}$ accumulations were 561.85 
and 1,645.86 $\mu \mathrm{g} \mathrm{Zn/} \mathrm{plant,} \mathrm{respectively.} \mathrm{The} \mathrm{results} \mathrm{strongly} \mathrm{indicated} \mathrm{that} \mathrm{TCd}$ and TZn in sugarcane at the end of the sixth months were higher than in the end of second month of the cultivation. This could result from the greater growth of plants with application of $\mathrm{P}$ fertilizers which increased the capacity of plant to accumulate $\mathrm{Cd}$ and $\mathrm{Zn}$.
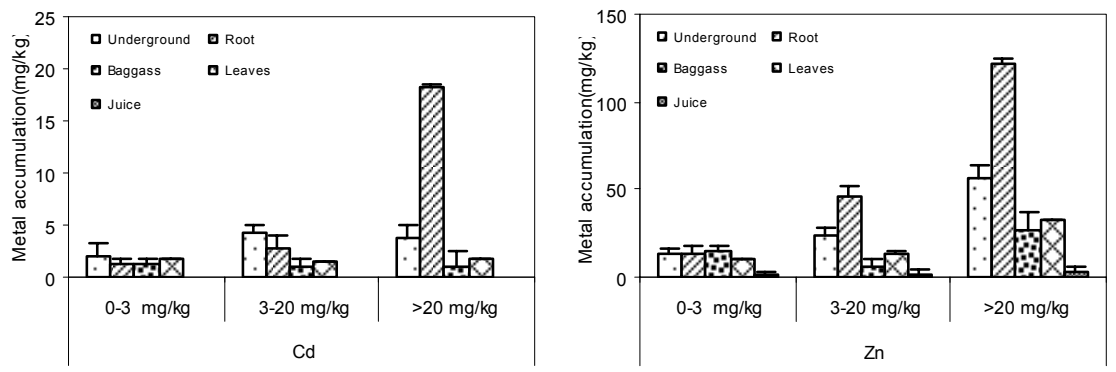

Figure 4: $\quad \mathrm{Cd}$ and $\mathrm{Zn}$ accumulation in different parts of sugarcane in field experiment at the end of the sixth month.
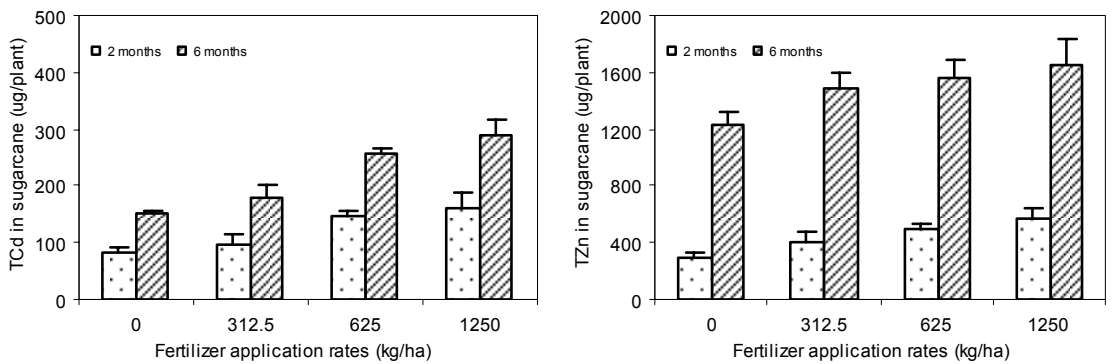

Figure 5: $\quad \mathrm{Cd}$ and $\mathrm{Zn}$ accumulation in pot experiment sugarcane under different rates of fertilizer.

For the chemical analysis of TCd and TZn accumulation in different parts of sugarcane at the end of the second month, sugarcane was botanically separated into only four parts (underground stems (setts), root, bagasses and leaf). Because of incomplete maturity of sugarcane juice was not available. The results show that most accumulation of $\mathrm{Cd}$ and $\mathrm{Zn}$ occurred in the roots followed by underground stems (setts), bagasses and leaves, respectively. The results show the same trend at the end of the sixth months of the cultivation. TCd and TZn accumulated in five parts of mature sugarcane had the following sequence: roots $>$ underground stems (setts) $>$ bagasses $>$ leaves $>$ juice (figure 6). The result shows low Cd contaminate in juice. Thus, it can be assumed safe to use as a raw material in ethanol production. 


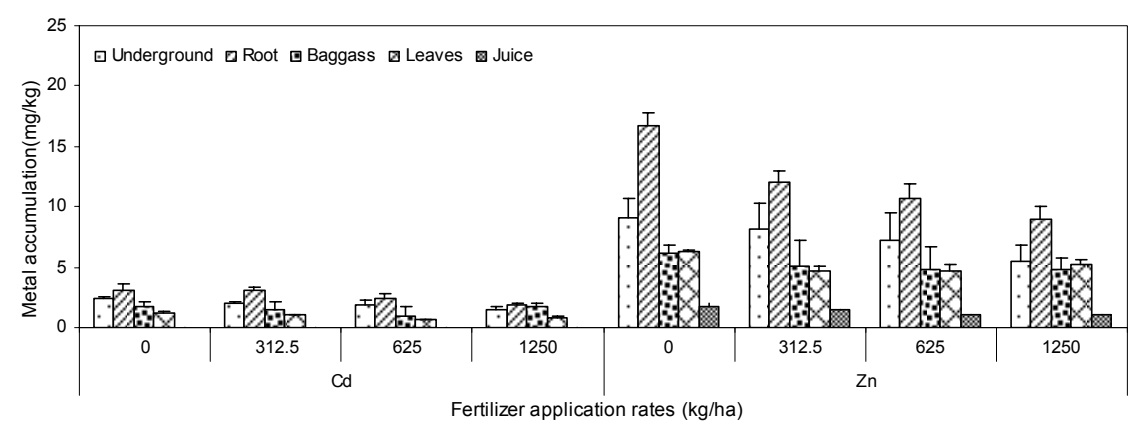

Figure 6: $\mathrm{Cd}$ and $\mathrm{Zn}$ accumulation in different parts of field experiment sugarcane at the end of the sixth month.

\section{Conclusions}

The addition of $312.5 \mathrm{~kg}$ fertilizer/ ha to sugarcane cultivated areas showed no effect on increasing $\mathrm{Cd}$ and $\mathrm{Zn}$ concentration in soils even with a repeat application of fertilizer in the fifth month of the cultivation. However, long-term effects of fertilization should be considered and need additional study. The phytoavailability of $\mathrm{Cd}$ and $\mathrm{Zn}$ to be taken up into sugarcane are proportional to the levels of $\mathrm{Cd}$ contaminate in sugarcane cultivated areas. The results showed no effect of fertilization on available $\mathrm{Cd}$ and $\mathrm{Zn}$. This could have resulted from already high $\mathrm{Cd}$ contamination in the sugarcane cultivated areas.

For the pot experiment, total $\mathrm{P}$ in all treatments of fertilized soil increased with increasing fertilizers application rates both at the end of the second and sixth months. However, they were lower in the sixth month when compared to the second month group. Increasing $\mathrm{P}$ as fertilizer is applied to soils can induce more $\mathrm{Cd}$ in an available form and promote take up and accumulation in different parts of the sugarcane. Therefore, TCd in soil would decrease. For Zn, at the end of the second month, phytoavailable $\mathrm{Zn}$ was lower in all rates of fertilized soil as compared to non-fertilized soil ( $0 \mathrm{~kg}$ fertilizer/ha). The decrease in $\mathrm{Zn}$ with fertilizer addition strongly suggests enhanced $\mathrm{Zn}$ adsorption on the surface due to $\mathrm{P}$ inputs or $\mathrm{P}-\mathrm{Zn}$ mineral precipitation. Also, $\mathrm{Zn}$ could be taken up more easily by sugarcane at the end of the sixth month because of decreasing $\mathrm{P}$ in the soil. $\mathrm{TCd}$ and TZn accumulation in different parts of sugarcane had the following sequence: roots $>$ underground stems (setts) $>$ bagasses $>$ leaves $>$ juice.

\section{Acknowledgements}

The authors gratefully acknowledge financial support from National Center of Excellence for Environmental and Hazardous Waste Management (NCEEHWM), Chulalongkorn University and Mae Sot Clean Energy Co, Ltd. Thailand. Additional gratitude goes to the Environmental Research Institute, 
Chulalongkorn University (ERIC) for assistance in providing academic facilities and research instrument support throughout this research.

\section{References}

[1] Department of Primary Industries and Mines. Cadmium Contamination in Environment, Mae Sot district, Tak province Online. www.dpim.go.th/dt/pper/000001085547312.pdf 2006.

[2] He Q. B. and Singh B. R. Plant availability of cadmium in soil I. Extractable cadmium in newly and long-term cultivated soils. Acta. Agric., 43, pp. 134-141, 1993.

[3] Williams C. H. and David D. J. The effect of superphosphate on the cadmium content of soils and plants. Aust. J. Soil Res., 11, pp. 43-56, 1973.

[4] Tu C., Zheng C. R. and Chen H. M. Effect of applying chemical fertilizers on forms of lead and cadmium in red soil. Chemosphere., 41, pp. 133-138, 2000.

[5] USEPA. Microwave assisted acid digestion of siliceous and organically based matrices. Method 3052, Washington D.C., USA., 1996.

[6] Jackson, M. L. Soil chemical analysis. New Jersey: Prentice Hall, Inc., 1973.

[7] AOAC. Phosphates and Phosphoric Acid. New York: Marcel Dekker Inc., 1975.

[8] Lindsay W. L. and Norvell W. A. Development of a DTPA soil test for zinc, iron, manganese, and copper. Soil Sci. Soc. Amer. J., 42, pp. 421-428, 1978.

[9] McLaughlin M. J., Singh B.R. Cadmium in soils and plants. Dordrecht: Kluwer Academic Publishers., 1999.

[10] Krishnamurti G. S. H., Huang P. M., Kozak L. M. Sorption and desorption kinetic of cadmium from soils: influence of phosphate. Soil Sci.,164,pp. 888-898,1999.

[11] Christensen T. Cadmium soil sorption at low concentration: II Reversibility, effect of charges in solutr composition and effect of soil aging. Water Air Soil Pollut., 21, pp. 115-125, 1994.

[12] Mench M., Vangronsveld J., Lepp N. W. and Edwards R. Physico-chemical aspects and efficiency of trace element immobilization by soils amendments. In: Metal-contaminated soils: in situ inactivation and phytorestoration, Vangronsveld J., Cunningham S. D., Springer-Verlag, pp. 151-182, 1998.

[13] McGowen S. L., Basta N. T. And Brown G. O. Use of diammonium phosphate to reduce heavy metal solubility and transport in smeltercontaminated soil. J. Environ. Qual., 30, pp. 493-500, 2001.

[14] Cotter-Howells J. and Caporn S. Remediation of contaminated lands by formation of heavy metal phosphates. Appl Geochem., 11, pp. 335-342, 1996. 
[15] Choudhary M., Bailey L. D., and Grant G. A. Effect of zinc on cadmium concentration in the tissue of durum wheat. Can. J. Plant. Sci., 74, pp. 549$552,1994$.

[16] Grant C. A. and Bailey L. D. Interactions of zinc with banded and broadcast phosphorus fertilizers on the concentration and uptake $\mathrm{P}, \mathrm{Zn}, \mathrm{Ca}$ and $\mathrm{Mg}$ in plant tissues of oilseed flax. Can. J. Plant. Sci., 73, pp. 17-29, 1997.

[17] Lambert R., Grant C. and Sauve S. Cadmium and zinc in soil solution extracts following the application of phosphate fertilizers. Sci. Total. Environ., 378, pp. 293-305, 2007.Grant C. A. and Bailey L. D. Interactions of zinc with banded and broadcast phosphorus fertilizers on the concentration and uptake $\mathrm{P}, \mathrm{Zn}, \mathrm{Ca}$ and $\mathrm{Mg}$ in plant tissues of oilseed flax. Can. J. Plant. Sci., 73, pp. 17-29, 1997. 